\title{
Pentacyclic triterpenoids and polyphenols accumulation in cell suspension culture of Chaenomeles japonica (Thunb.) Lindl. ex Spach
}

\author{
MAŁGORZATA KIKOWSKA ${ }^{1}$, AGATA WŁODARCZYK ${ }^{1}$, ANNA STOCHMAL ${ }^{2}$, JERZY ŻUCHOWSKI², \\ BARBARA THIEM ${ }^{1 *}$
}

\author{
${ }^{1}$ Department of Pharmaceutical Botany and Plant Biotechnology \\ Poznan University of Medical Sciences \\ Św. Marii Magdaleny 14, \\ 61-861 Poznań, Poland \\ ${ }^{2}$ Department of Biochemistry and Crop Quality \\ Institute of Soil Science and Plant Cultivation \\ State Research Institute \\ Czartoryskich 8, \\ 24-100 Puławy, Poland \\ * corresponding author: e-mail: bthiem@ump.edu.pl
}

\section{Summary}

Introduction: Callus and cell suspension cultures are widely applied in investigation of production of highvalue secondary metabolites, which may be used as cosmeceuticals, nutraceuticals and pharmaceuticals. Plant cell cultures are promising alternative to intact plant sources for the production of plant-derived drugs of industrial importance.

Objective: The aim of the study was to (i) initiate the cell suspension culture of Chaenomeles japonica from homogenous and uniform callus, (ii) stabilize the selected line and (iii) verify its ability to produce the desired groups of secondary metabolites - pentacyclic triterpenoids and polyphenols.

Methods: To establish a cell suspension culture, stabilized and homogeneous callus was selected. Cell cultures were systematically passaged every 2 weeks to fresh liquid medium with the same composition. Biomass from cultures at the growth phase and stationary phase was designated for phytochemical research. UHPLC-DAD-MS analyzes were performed. At the same time, their macroscopic and microscopic observations were carried out.

Results: Cells of suspension culture line A2 were characterized by the intense divisions. Cell culture extracts (both from the growth phase and stationary phase) contained pentacyclic triterpenoids. In addition, phe- 
nolic compounds (chlorogenic acid and proanthocyanidins type B) and in a small amount also epicatechin are present in the extract of the cells harvested from the growth phase. In the present studies, three pentacyclic triterpenoids were detected and quantified in the extracts of cell suspensions and callus line A2. Ursolic and oleanolic acids were the main triterpenoids in the studied extracts. The cell suspension culture from the growth phase exhibited the highest content of ursolic, oleanolic, and betulinic acid (separately and together).

Conclusion: The cell suspension culture of Chaenomeles japonica is a promising source of pentacyclic triterpenoids.

Key words: Japanese quince, callus, cell suspension culture, chlorogenic acid, ursolic acid, oleanolic acid Słowa kluczowe: pigwowiec japoński, kalus, kultura zawiesinowa, kwas chlorogenowy, kwas ursolowy, kwas oleanolowy

\section{INTRODUCTION}

Chaenomeles japonica (Thunb.) Lindl. ex Spach belongs to the subfamily Maloideae of the Rosaceae. C. japonica, a dwarf shrub naturally occurs in Central and South Japan [1]. In Europe, the plant was introduced in XIX century, and it has been appreciated for its ornamental value [2]. The high content of vitamin C, organic acids, phenolic compounds, dietary fiber, pectin, simple sugars of the fruits of C. japonica, make them well suited for industrial processing $[3,4]$.

Phytochemical studies have yielded secondary metabolites in selected raw materials of $C$. japonica - epicatechin, leucoanthocyanin, monoterpene glucosides, and roseoside in fruits; flavonol glycosides and epicatechin in leaves; and three pentacyclic triterpenoids (ursolic, oleanolic, and pomolic acids), daucosterol, prunasin and epicatechin in roots [5]. Among representatives of the genus Chaenomeles, in traditional medicine of Far East, the fruits of Chaenomeles speciosa were used for centuries as 'Mugua', while the fruits of $C$. japonica have been used as an astringent and in stomach diseases [6]. Moreover, the extract from seeds of C. japonica is on the list of cosmetic ingredients approved for use in the European Union acting as a supplement that nourishes the skin [7].

There is a growing interest in pentacyclic triterpenoids due to their interesting potential biological and pharmaceutical properties. Pentacyclic triterpenoids are a class of compounds occurring in several medicinal plants. Oleanolic acid and its isomer - ursolic acid have long been known to be anti-inflammatory, hepatoprotective, and anti-hyperlipidemic in traditional medicine of Asia. Moreover, recently there are many studies on the antiviral, antimicrobial and anticancer activities [8]. Betulinic acid is highly regarded for its anti-HIV-1 activity and cytotoxicity against cancer lines, but also was reported for its cosmetic properties [9].

Polyphenols are the most common bioactive compounds widely distributed in plants. They exhibit a great diversity and are divided into several classes i.e. phenolic acids, flavonoids, and proanthocyanidins. The phenolic constituents have a wide range of biological activities, mainly attributed to their antioxidant potential [10]. The main phenolic acid occurring in C. japonica is chlorogenic acid, which is well-known polyphenol exerting many biological activities i.e. antioxidant, antimicrobial, antipyretic, hepatoprotective, cardioprotective, anti-inflammatory, anticarcinogenic, and glucose and lipid metabolism modulatory [11].

Callus and cell suspension cultures are widely applied in investigation of high-value secondary metabolites production, which may be used as cosmeceuticals, nutraceuticals and pharmaceuticals. Plant cell cultures, with the continuous and reliable accumulation of desired bioactive compounds, are promising alternative to intact plant sources for the production of plant-derived drugs of industrial importance. In comparison with the conventional cultivation of plants, plant cell cultures offer an independent of geographical and environmental factors supply of uniform biomass with enhanced production of active constituents. Plant in vitro cultures ensures a rational utilization of biodiversity $[12,13]$.

The aim of the study was to (i) initiate the cell suspension culture of Chaenomeles japonica from homogenous and uniform callus, (ii) stabilize the selected line and (iii) verify its ability to produce desired groups of secondary metabolites - pentacyclic terpenoids and polyphenols. To our knowledge, this is the first report about production of polyphenols and pentacyclic triterpenoids in callus and cell suspension cultures of Chaenomeles japonica. 


\section{MATERIAL AND METHODS}

\section{Plant material}

A voucher specimen of $C$. japonica was deposited in the herbarium of Department of Pharmaceutical Botany and Plant Biotechnology, Poznań, Poland, under the number 1526/2016.

The explants were taken from an old shrub growing in open environment conditions in Poznań. The seeds were surface disinfected and transferred to MS [14] medium to obtain the aseptic seedlings, which were the sources of explants for micropropagation (according to the paper [15]). Briefly, the mature seeds were washed under tap water for $1 \mathrm{~min}$ and then rinsed in distilled water for $5 \mathrm{~min}$ followed by submerging in $70 \%(\mathrm{v} / \mathrm{v}) \mathrm{EtOH}$ for $30 \mathrm{~s}$. They were rinsed in sterilized water and placed on lignin in thermostat $\left(26^{\circ} \mathrm{C}\right)$ for $24 \mathrm{~h}$. The accurate disinfection step was to treat the seeds with commercial bleach at a concentration of $50 \%$ for $20 \mathrm{~min}$. Then they were rinsed five times in sterilized distilled water and transferred to MS medium to obtain the aseptic seedlings. After four weeks in vitro-germinated seedlings were the sources of explants for proliferation of the new shoots. The media were enriched with BA $1.0 \mathrm{mg} \cdot \mathrm{l}^{-1}$ and IAA $1.0 \mathrm{mg} \cdot \mathrm{l}^{-1}$. The shoots were multiplied by repetitive transfer of explants to the freshly prepared medium every six weeks.

The media variants for callus initiation and proliferation were initially tested and the four callus lines with the best growth indexes were selected for the further investigations (according to the paper [16]). Briefly, callus was inducted on young leaves (blades and petioles) of micropropagated plantlets. The media were enriched with 2,4-D 1.0 mg.l ${ }^{-1}+$ KIN 0.1 mg.l ${ }^{-1}, 2,4-D 1.0$ mg.l $l^{-1}+$ KIN 1.0 mg. ${ }^{-1}, 2,4-D 2.0$ mg. $1^{-1}+$ KIN 1.0 mg.1 ${ }^{-1}, 2,4-D$ $0.5 \mathrm{mg} \cdot \mathrm{l}^{-1}+\mathrm{NAA} 0.05 \mathrm{mg} \cdot \mathrm{l}^{-1}, 2,4-\mathrm{D} 1.0 \mathrm{mg} \cdot \mathrm{l}^{-1}+\mathrm{NAA}$ $0.1 \mathrm{mg} \cdot \mathrm{l}^{-1}, 2,4-\mathrm{D} 2.0 \mathrm{mg} \cdot \mathrm{l}^{-1}+\mathrm{NAA} 0.2 \mathrm{mg} \cdot \mathrm{l}^{-1}, 2,4-\mathrm{D}$ $1.0 \mathrm{mg} \cdot \mathrm{l}^{-1}, 2,4-\mathrm{D} 2.0 \mathrm{mg} \cdot \mathrm{l}^{-1}$, DIC $1.0 \mathrm{mg} \cdot \mathrm{l}^{-1}$, or DIC $2.0 \mathrm{mg} \cdot \mathrm{l}^{-1}$ (Table 1). Subcultures were performed at 4-week intervals. Callus initiation and its development were first observed visually, and then when callus culture became stabilized (5-7 passages), the growth callus index was calculated (Table 2) by the following equation: Growth index $=($ final cell weight - initial cell weight $) /$ initial cell weight.

The four lines of stabilized callus were selected for cell suspension culture initiation: A1 - callus from MS + 2,4-D $1.0 \mathrm{mg} \cdot \mathrm{l}^{-1}+\mathrm{KIN} 0.1 \mathrm{mg} \cdot \mathrm{l}^{-1}$ (light), A2 - callus from MS + 2,4-D $1.0 \mathrm{mg} \cdot \mathrm{l}^{-1}+\mathrm{KIN}$ $0.1 \mathrm{mg} \cdot \mathrm{l}^{-1}$ (darkness), $\mathbf{B}-$ callus from MS $+2,4-\mathrm{D}$ $2.0 \mathrm{mg} \cdot \mathrm{l}^{-1}+\mathrm{NAA} 0.2 \mathrm{mg} \cdot \mathrm{l}^{-1}$, and $\mathrm{C}$ - callus from MS + DIC $1.0 \mathrm{mg} \cdot \mathrm{l}^{-1}$.

\section{Culture conditions}

Each medium for callus and cell suspension growth (the same phytohormonal variant) was adjusted to $\mathrm{pH} 5.8$ before autoclaving at $121^{\circ} \mathrm{C} / 105 \mathrm{kPa}$ for

Table 1

Induction of Chaenomeles japonica callus from leaves placed on various variants of MS medium (PGRs - Plant Growth Regulators)

\begin{tabular}{|c|c|c|c|c|}
\hline \multirow{2}{*}{$\begin{array}{c}\text { MS with PGRs } \\
{\left[\mathrm{mg} \cdot \mathrm{l}^{-1}\right]}\end{array}$} & & \multicolumn{3}{|c|}{ Callus parameters } \\
\hline & & Induction & Colour & Structure \\
\hline 2,4-D 1.0 & - & + & yellow & friable, hard \\
\hline 2,4-D 2.0 & - & + & yellow & friable, hard \\
\hline 2,4-D 1.0 & KIN 0.1 & +++ & yellow, pink-yellow & friable, soft \\
\hline 2,4-D 1.0 & KIN 1.0 & ++ & yellow, yellow-brown & friable, hardened \\
\hline 2,4-D 2.0 & KIN 1.0 & ++ & yellow, yellow-brown & friable, hardened \\
\hline 2,4-D 0.5 & NAA 0.05 & ++ & yellow, white-yellow & slightly watery \\
\hline 2,4-D 1.0 & NAA 0.1 & ++ & yellow, white-yellow & friable \\
\hline 2,4-D 2.0 & NAA 0.2 & +++ & white & downy, friable \\
\hline DIC 1.0 & - & +++ & pink & slightly watery \\
\hline DIC 2.0 & - & ++ & pink, pink - brown & nodular \\
\hline
\end{tabular}

2,4-D - dichlorophenoxyacetic acid; DIC - dicamba; KIN - kinetin; MS - Murashige and Skoog medium; NAA - 1-naphthaleneacetic acid 
Table 2

Growth parameters of selected lines of Chaenomeles japonica callus growing on various variants of MS medium (PGRs - Plant Growth Regulators)

\begin{tabular}{|c|c|c|c|c|c|c|}
\hline \multirow{2}{*}{ Plant material } & \multirow{2}{*}{\multicolumn{2}{|c|}{$\begin{array}{c}\text { MS with PGRs } \\
{\left[\mathrm{mg}^{-1}\right]}\end{array}$}} & \multicolumn{4}{|c|}{ Callus growth index $[\%] \pm \mathrm{SE}^{*}$} \\
\hline & & & Passage 5 & Passage 6 & Passage 7 & Mean \\
\hline Callus line A1 light & 2,4-D 1.0 & KIN 0.1 & $404.04 \pm 58.90$ & $831.51 \pm 48.83$ & $867.43 \pm 13.58$ & $854.26 \pm 13.58$ \\
\hline Callus line A2 dark & 2,4-D 1.0 & KIN 0.1 & $503.94 \pm 58.60$ & $907.21 \pm 1.82$ & $978.59 \pm 14.45$ & $960.46 \pm 14.24$ \\
\hline Callus line B & 2,4-D 2.0 & NAA 0.2 & $372.32 \pm 30.67$ & $804.36 \pm 44.15$ & $824.28 \pm 12.66$ & $808.56 \pm 38.56$ \\
\hline Callus line C & DIC 1.0 & - & $418.82 \pm 16.66$ & $458.66 \pm 9.77$ & $480.59 \pm 5.98$ & $480.59 \pm 5.98$ \\
\hline
\end{tabular}

2,4-D - dichlorophenoxyacetic acid; DIC - dicamba; KIN - kinetin; MS - Murashige and Skoog medium; NAA - 1-naphthaleneacetic acid

20 min. Plant growth regulators (PGRs) originated from Sigma-Aldrich (St. Louis, MO, USA). The cultures were maintained in a growth chamber $(16 / 8 \mathrm{~h}$ photoperiod, $55 \mu \mathrm{mol} \mathrm{m}^{-2} \mathrm{~s}^{-1}$ light, temp. $21 \pm 2^{\circ} \mathrm{C}$ ).

\section{Cell suspension culture initiation and maintenance}

To establish a cell suspension culture, stabilized, homogeneous, friable, light and slightly hydrated callus was selected. Under aseptic conditions, the inoculum was experimentally selected $( \pm 1 \mathrm{~g})$ and transferred to a $250 \mathrm{~cm}^{3}$ flask, with $50 \mathrm{ml}$ of liquid medium (Fig. 1,2). Callus was wiped through a sieve to crush the tissue. The flasks of cell suspension were placed in a growth chamber, on a rotary shaker (110 rpm), in the dark. Cell cultures were systematically passaged ( $5 \mathrm{ml}$ inoculum) every 2 weeks to fresh liquid medium with the same composition. Biomass was collected between $8^{\text {th }}$ and $10^{\text {th }}$ passage for phytochemical studies. Biomass from cultures at the growth phase (GP; light colour; $8^{\text {th }}-10^{\text {th }}$ day) and stationary phase (SP; dark colour; $20^{\text {th }}$ day) was designated for phytochemical research. The cells were frozen and then lyophilized to obtain material for further investigation. At the same time, their macroscopic and microscopic (optical microscope Leica IMS500 HD) observations were carried out.

\section{Phytochemical analysis}

Biomass of callus and cell suspension culture was taken for phytochemical analysis. In order to prepare samples, the in vitro culture material was frozen and then subjected to lyophilization. The samples $(100 \mathrm{mg})$ were ground in a mortar and extracted with $80 \%(v / v)$ methanol (HPLC isocratic grade, Merck Millipore, Darmstadt, Germany) using the accelerated solvent extraction system (ASE 200, Dionex, Sunnyvale, CA, USA). Extraction was carried out at $100^{\circ} \mathrm{C}$, operating pressure was $10.3 \mathrm{MPa}$. The extracts were evaporated to dryness, suspended in $5 \% \mathrm{MeOH}$, and subjected to solid phase extraction (SPE) on a Waters SepPak Classic cartridge equilibrated with $5 \% \mathrm{MeOH}$. The analytes were eluted with $95 \% \mathrm{MeOH}$, evaporated to dryness and reconstituted in $3.000 \mathrm{ml}$ of $90 \%$ $\mathrm{MeOH}$. The samples were then stored in $-20^{\circ} \mathrm{C}$ and, before the analyses, they were centrifuged at $23000 \mathrm{x}$ $\mathrm{g}$ for $15 \mathrm{~min}$. UHPLC-DAD-ESI-MS analyzes were performed using an ACQUITY UPLC' chromatographic system (Waters Corp., Milford, MA, USA), equipped with a triple quadrupole mass detector. For the determination of the content of oleanolic, ursolic and betulinic acids, an ACQUITY HSS C18 column $(2.1 \times 100 \mathrm{~mm}, 100 \AA, 1.8 \mu \mathrm{m}$; Waters $)$ was used, flow rate was $0.400 \mathrm{ml} \mathrm{min}{ }^{-1}\left(30^{\circ} \mathrm{C}\right)$, the injection volume was $2.5 \mu \mathrm{l}$, the isocratic elution with $80 \%$ methanol (HPLC gradient grade, Merck Millipore) containing $0.1 \%$ formic acid (LC-MS grade, Merck Millipore) was applied (11.9 min). The column was subsequently washed with $99 \%$ $\mathrm{MeOH}(0.1 \%$ formic acid) $(12-13 \mathrm{~min})$, then the initial conditions were restored (13.1-15.0 min). Detection of the acids by mass spectrometry was carried out in the negative ionization mode, using the Selected Ion Monitoring (SIM) method. The following MS settings were applied: capillary voltage was $2.8 \mathrm{kV}$; cone voltage $80 \mathrm{~V}$; source temperature $140^{\circ} \mathrm{C}$, desolvation temperature $350^{\circ} \mathrm{C}$, cone gas flow (nitrogen) $100 \mathrm{l} \cdot \mathrm{h}^{-1}$, desolvation gas flow $800 \mathrm{l} \cdot \mathrm{h}^{-1}$. Content of ursolic and oleanolic acid in the investigated samples was determined by external calibration, using authentic standards (ursolic acid and oleanolic acid Sigma-Aldrich: 6 solutions 


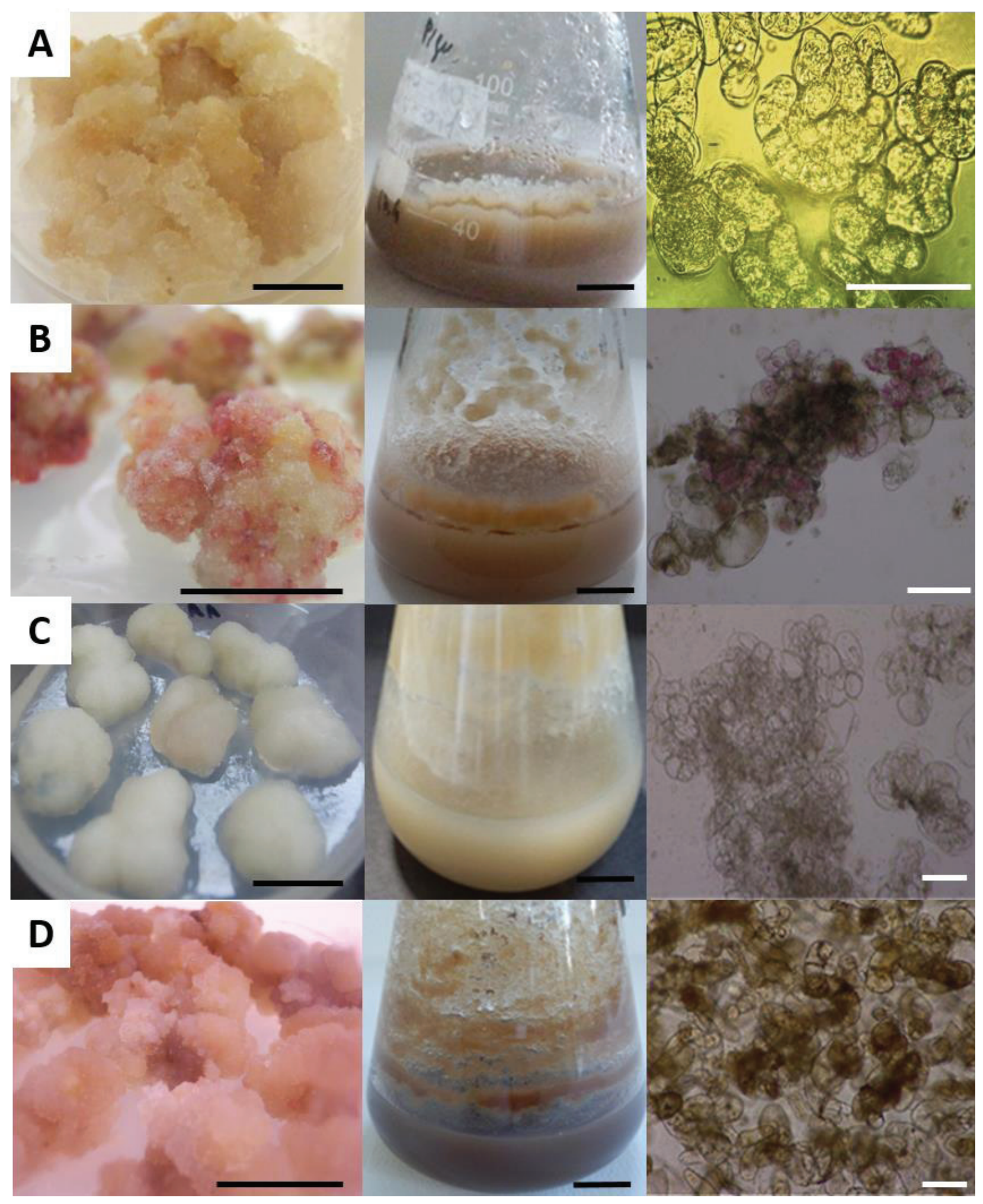

Figure 1

Macroscopic and microscopic images of callus and cell suspension cultures of Chaenomeles japonica growing (A) in the dark on MS with 2,4-D $1.0 \mathrm{mg} \cdot \mathrm{l}^{-1}+\mathrm{KIN} 0.1 \mathrm{mg} \cdot \mathrm{l}^{-1}$; (B) in the light on MS with 2,4-D $1.0 \mathrm{mg} \cdot \mathrm{l}^{-1}+\mathrm{KIN} 0.1 \mathrm{mg} \cdot \mathrm{l}^{-1}$; (C) in the dark on MS with 2,4D $2.0 \mathrm{mg} \cdot \mathrm{l}^{-1}+$ NAA $0.2 \mathrm{mg} \cdot \mathrm{l}^{-1}$; (D) in the dark on MS with DIC $1.0 \mathrm{mg} \cdot \mathrm{l}^{-1}$ (black scale $=1 \mathrm{~cm}$; white scale $=500 \mu \mathrm{m}$ ) 


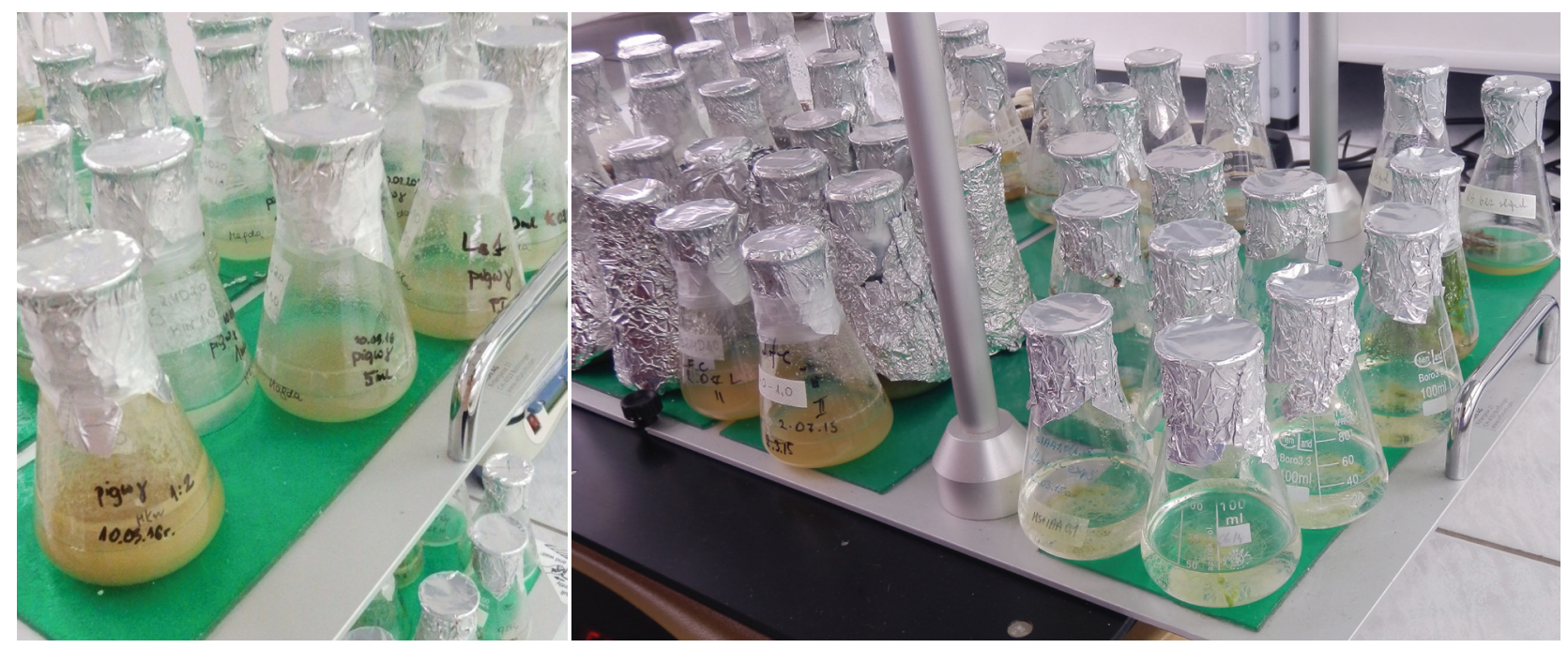

Figure 2

Cell suspension cultures of Chaenomeles japonica on a rotary shaker in a growth chamber

$1.0-50 \mu \mathrm{g} \cdot \mathrm{ml}^{-1}, \mathrm{y}=-456.02 \mathrm{x}^{2}+52103 \mathrm{x}+70463$, $\mathrm{R}^{2}=0.991$; ursolic acid: 6 solutions $1.0-50 \mu \mathrm{g} \cdot \mathrm{ml}^{-1}$, $\left.y=-339.1 x^{2}+40079 x+67659, R^{2}=0.990\right)$. Betulinic acid content was expressed as oleanolic acid equivalent. For testing the qualitative composition of samples and determining the content of phenolic compounds, an ACQUITY BEH C18 column $(2.1 \times 100 \mathrm{~mm}, 130 \AA, 1.7 \mu \mathrm{m}$; Waters $)$ was used, gradient elution using acetonitrile (LC-MS grade, Merck Millipore) with $0.1 \%$ formic acid (as above) and $0.1 \%$ formic acid in water as mobile phase components $\left(0.500 \mathrm{ml} \cdot \mathrm{min}^{-1}, 50^{\circ} \mathrm{C}\right)$. The injection volume was $2.5 \mu \mathrm{l}$. The following elution program was applied: $0-0.5 \mathrm{~min}, 7 \% \mathrm{~B}$; $0.5-11.9 \mathrm{~min}$, $7-80 \%$ B; 11.9 - 12.0 min, $80-95 \%$ B; 12.0 - 13.0, $95 \% \mathrm{~B} ; 13.0$ - $13.1 \mathrm{~min}, 95-7 \% \mathrm{~B} ; 13.1$ - $15 \mathrm{~min}$, $7 \% \mathrm{~B}$. The MS analysis was carried out using the scanning method in the positive and negative ionization mode. The MS settings for the negative ionization mode were as follows: capillary voltage was $2.8 \mathrm{kV}$; cone voltage $45 \mathrm{~V}$; source temperature $140^{\circ} \mathrm{C}$, desolvation temperature $350^{\circ} \mathrm{C}$, cone gas flow (nitrogen) $100 \mathrm{l} \cdot \mathrm{h}^{-1}$, desolvation gas flow $800 \mathrm{l} \cdot \mathrm{h}^{-1}$; positive ionization: capillary voltage was $3.1 \mathrm{kV}$, cone voltage $60 \mathrm{~V}$, other settings - as above. Constituents of the investigated extracts were tentatively identified and classified on the basis of their UV spectra and/or MS data. Chlorogenic acid and other phenolics were quantified or semi-quantified on the basis of UV chromatograms, using a calibration curve of chlorogenic acid (Sigma-Aldrich; 6 solutions $2.3-184 \mu \mathrm{g} \cdot \mathrm{ml}^{-1}, \mathrm{y}=182.94 \mathrm{x}-560.94$, $\left.\mathrm{R}^{2}=0.9981\right)$. Contents of other phenolics were expressed as chlorogenic acid equivalents.
Extractions and analyzes were performed in triplicate, the presented results are means with standard deviation.

Ethical approval: The conducted research is not related to either human or animal use.

\section{RESULTS AND DISCUSSION}

Callus initiation took place from the cut edges of the leaf explants of Chaenomeles japonica on all tested media. Some combinations of plant growth regulators stimulated callus formation - this callus easily proliferated, was very soft and friable (Table 1). The growth parameters for the four fast-growing lines callus (5-7 subcultures) were calculated (Table 2). From those selected callus lines (Fig. 1), the cell suspensions were initiated (Fig. 1, 2).

The microscopic image of the cell culture established from the callus cultivated on MS with 2,4-D $1.0 \mathrm{mg} \cdot \mathrm{l}^{-1}$ and KIN $0.1 \mathrm{mg} \cdot \mathrm{l}^{-1}$ in the light (line A1) showed small, round and elongated cells, slightly pink in colour. The cells of the suspension culture established from the callus cultivated on the same medium in the dark (line A2) were characterized by the intense divisions. Small, round, dividing cells formed small aggregates. This culture presented the best biomass growth. The cell culture originated from the callus on MS +2,4-D $2.0 \mathrm{mg} \cdot \mathrm{l}^{-1}$ and NAA $0.2 \mathrm{mg} \cdot \mathrm{l}^{-1}$ was characterized by the very high density of cells with different shapes, intensely dividing. The cell culture from the callus established on MS + DIC $1.0 \mathrm{mg} \cdot \mathrm{l}^{-1}$ was the only cell culture 
that had cells turning brown, mostly aging and elongated (Fig. 1).

For the first time, the cell suspension culture of C. japonica was maintained. The biomass obtained from the selected cell culture established from the callus A2 line growing on the medium MS + 2,4-D $1.0 \mathrm{mg} \cdot \mathrm{l}^{-1}$ and KIN $0.1 \mathrm{mg} \cdot \mathrm{l}^{-1}$ was collected for phytochemical studies. The line was chosen on the basis on fast biomass growth.

Callus and cell suspension cultures were tested in order to investigate their potential for the accumulation of two group of compounds - pentacyclic triterpenoids and selected polyphenols. UHPLC-MS analyses showed the presence of different putative triterpenoids in the callus and suspension cultures (Table 3, Fig. 3, 4). Most of them were tentatively identified on the basis of the MS data, as well as literature information $[5,17]$. Three compounds, giving deprotonated ions of $m / z 455$, were selectively detected during additional UHPLC-MS analyses (SIM mode). Two of them were identified as oleanolic and ursolic acid, by comparison with authentic standards; the third compound was tentatively identified as betulinic acid, which was previously detected in $C$. japonica

Table 3

The content $\left(\mathrm{mg}^{-1} \mathrm{~g}^{-1}\right)$ of selected pentacyclic triterpenoids in methanol-water extracts of Chaenomeles japonica biomass from in vitro cultures

\begin{tabular}{|c|c|c|c|c|}
\hline \multicolumn{5}{|c|}{ Pentacyclic triterpenoids $\left[\mathrm{mg}^{-1} \mathrm{~g}^{-1}\right.$ d. w. } \\
\hline Plant material & Ursolic acid & Oleanolic acid & Betulinic acid * & SUM \\
\hline $\begin{array}{c}\text { Callus line A2 } \\
\left(\mathrm{MS}+2,4-\mathrm{D} 1.0 \mathrm{mg} \cdot \mathrm{l}^{-1}+\mathrm{KIN} 0.1 \mathrm{mg} \cdot \mathrm{l}^{-1}\right) \text { dark }\end{array}$ & $5.00 \pm 0.61$ & $4.35 \pm 0.30$ & $0.459 \pm 0.025$ & $9.809 \pm 0.891$ \\
\hline $\begin{array}{c}\text { Cell suspension culture } \\
\left(\mathrm{MS}+2,4-\mathrm{D} 1.0 \mathrm{mg} \cdot \mathrm{l}^{-1}+\mathrm{KIN} 0.1 \mathrm{mg} \cdot \mathrm{l}^{-1}\right) \\
\text { from growth phase (light) }\end{array}$ & $9.37 \pm 0.49$ & $7.54 \pm 0.52$ & $0.757 \pm 0.054$ & $17.667 \pm 1.061$ \\
\hline $\begin{array}{c}\text { Cell suspension culture } \\
\left(\mathrm{MS}+2,4-\mathrm{D} 1.0 \mathrm{mg} \cdot \mathrm{l}^{-1}+\mathrm{KIN} 0.1 \mathrm{mg} \cdot \mathrm{l}^{-1}\right) \\
\text { from stationary phase (dark) }\end{array}$ & $4.43 \pm 0.16$ & $5.89 \pm 0.22$ & $0.642 \pm 0.021$ & $10.962 \pm 0.451$ \\
\hline
\end{tabular}

2,4-D - dichlorophenoxyacetic acid; DIC - dicamba; KIN - kinetin; MS - Murashige and Skoog medium

* expressed as oleanolic acid equivalent

PENTACYCLIC TRITERPENES

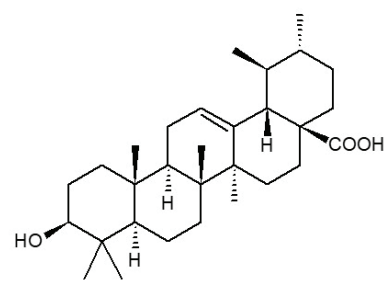

ursolic acid

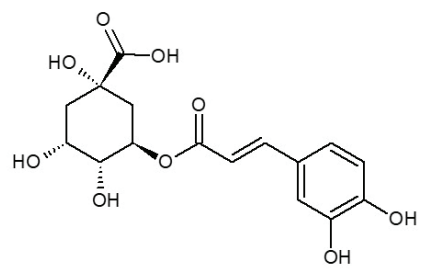

chlorogenic acid

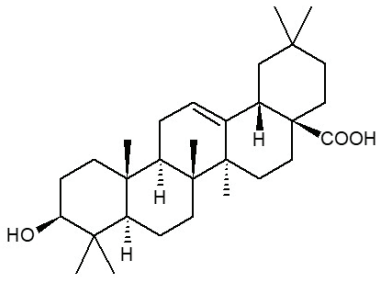

oleanolic acid

POLYPHENOLS<smiles>Oc1cc(O)c2c(c1)O[C@H](c1ccc(O)c(O)c1)[C@H](O)C2</smiles>

(-)-epicatechin

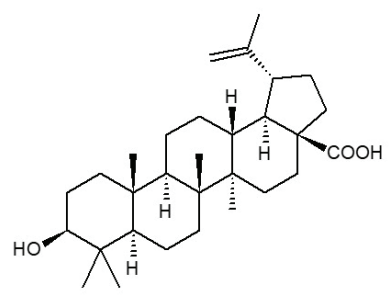

betulinic acid<smiles>[R20]c1c(-c2ccc(O)c(O)c2)oc2cc(O)cc(O)c2c1=O</smiles>

quercetin-3-hexoside

$\mathrm{R}=$ unspecified hexose moiety

Figure 3

Chemical structures of main pentacyclic triterpenes and polyphenols of Chaenomeles japonica cell cultures 

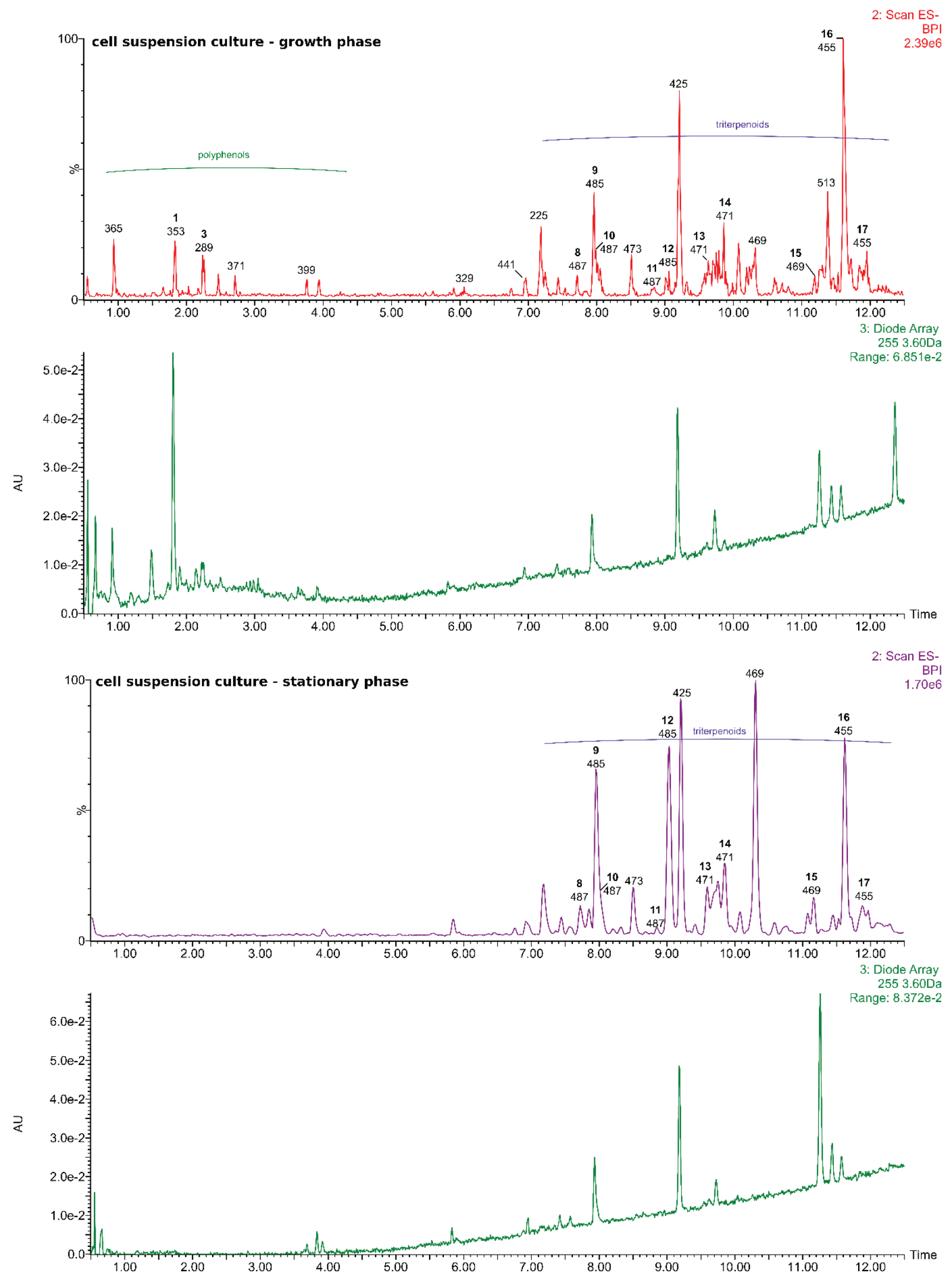


\begin{tabular}{llll} 
No & tR $(\mathrm{min})$ & {$[\mathrm{M}-\mathrm{H}]-(\mathrm{m} / \mathrm{z})$} & identification \\
\hline 1 & 1.81 & 353 & chlorogenic acid $^{*}$ \\
\hline 2 & 2.00 & 577 & dimeric proanthocyanidin \\
\hline 3 & 2.22 & 289 & epicatechin \\
\hline 4 & 2.28 & 337 & coumaroylquinic acid \\
\hline 5 & 2.46 & 1153 & tetrameric proanthocyanidin \\
\hline 6 & 3.05 & 463 & quercetin hexoside \\
\hline 7 & 3.38 & 515 & dicaffeoylquinic acid \\
\hline 9 & 7.71 & 487 & triterpenoid \\
\hline 10 & 8.95 & 485 & triterpenoid \\
\hline 11 & 8.85 & 487 & triterpenoid \\
\hline 12 & 9.05 & 487 & triterpenoid \\
\hline 13 & 9.68 & 485 & triterpenoid \\
\hline 14 & 9.86 & 471 & triterpenoid \\
\hline 15 & 11.17 & 471 & triterpenoid \\
\hline 16 & 11.62 & 469 & triterpenoid \\
\hline 17 & 11.89 & 455 & betulinic acid \\
\hline & & 455 & oleanolic \& ursolic acid \\
\hline
\end{tabular}

* confirmed by the comparison with an authentic standard

Figure 4

UHPLC-MS chromatograms of methanol-water extracts of cell suspension cultures of Chaenomeles japonica from growth phase and stationary phase maintained in MS medium with 2,4-D $1.0 \mathrm{mg} \cdot \mathrm{l}^{-1}+\mathrm{KIN} 0.1 \mathrm{mg} \cdot \mathrm{l}^{-1}$ (ESI Base Peak chromatograms and UV chromatograms)

fruit by Yang et al. [17]. The highest amounts of ursolic acid $\left(9.37 \pm 0.47 \mathrm{mg} \cdot \mathrm{g}^{-1} \mathrm{~d}\right.$.w. $)$ and oleanolic acid $\left(7.54 \pm 0.52 \mathrm{mg} \cdot \mathrm{g}^{-1}\right.$ d.w. $)$ were found in cell suspension biomass from growth phase (Table 3 ). In addition, some phenolic compounds, mainly chlorogenic acid, B type proanthocyanidins and epicatechin were present in the callus (Table 4) and cells harvested from the growth phase. In contrast, cells from the stationary phase were virtually devoid of phenolics (Fig. 3, 4). Among all phenolics in all tested systems, the main compound was chlorogenic acid. The highest accumulation was detected in the callus (1.094 \pm $0.081 \mathrm{mg} \cdot \mathrm{g}^{-1} \mathrm{~d} . \mathrm{w}$.) and cell suspension culture from growth phase $\left(0.545 \pm 0.040 \mathrm{mg} \cdot \mathrm{g}^{-1} \mathrm{~d}\right.$.w.) (Table 4).

Production of pentacyclic triterpenoids in callus and cell suspension cultures of different plant species is available $[18,19]$. In the present studies, the three pentacyclic triterpenoids were detected and quantified in the extracts of the cell suspensions and callus line $\mathrm{A} 2$, from which the cells cultures were obtained (Table 3). Ursolic and oleanolic acids were probably the main triterpenoids in the studied extracts. The cell suspension culture from the growth phase exhibited the highest content of ursolic (UA), oleanolic (OA), and betulinic acids (BA) (separately and as the sum). As mentioned in the literature, there are only few reports on the simultaneous presence of ursolic, oleanolic, and betulinic acids occurring together in cell cultures. Those three pentacyclic triterpenoids were determined in cell cultures of Lantana camara in an enhanced yield of UA $-4.12 \%, \mathrm{OA}-1.88 \%$ and BA - 3.1\% [20, 21]. In cell cultures of Hyssopus officinalis, Skrzypek and Wysokińska [22] identified also the presence of UA and OA. The maximum production of terpenoides in cell suspension culture of Centella asiatica was observed in the stationary phase [23].

In addition, four polyphenolic compounds were analysed in the tested extracts. Chlorogenic acid, dicaffeoylquinic acid, epicatechin and a quercetin hexoside were detected in the callus line A2 and in a little amount in cell suspension culture at the growth phase. The main polyphenolic constituent 


\section{Table 4}

The content $\left(\mathrm{mg} \cdot \mathrm{g}^{-1}\right)$ of selected pentacyclic triterpenoids in methanol-water extracts of Chaenomeles japonica biomass from in vitro cultures

\begin{tabular}{|c|c|c|c|c|}
\hline \multirow[b]{2}{*}{ Plant material } & \multicolumn{4}{|c|}{ Pentacyclic triterpenoids $\left[\mathrm{mg} \cdot \mathrm{g}^{-1}\right]$ d. w. } \\
\hline & Chlorogenic acid & Dicaffeoylquinic acid ${ }^{*}$ & Epicatechin* & Quercetin hexoside \\
\hline $\begin{array}{c}\text { Callus line A2 } \\
\left(\mathrm{MS}+2,4-\mathrm{D} 1.0 \mathrm{mg} \cdot \mathrm{l}^{-1}+\mathrm{KIN} 0.1 \mathrm{mg} \cdot \mathrm{l}^{-1}\right) \text { dark }\end{array}$ & $1.094 \pm 0.081$ & $0.077 \pm 0.006$ & $0.068 \pm 0.008$ & $0.064 \pm 0.008$ \\
\hline $\begin{array}{c}\text { Cell suspension culture } \\
\left(\mathrm{MS}+2,4-\mathrm{D} 1.0 \mathrm{mg} \cdot \mathrm{l}^{-1}+\mathrm{KIN} 0.1 \mathrm{mg} \cdot \mathrm{l}^{-1}\right) \\
\text { from growth phase (light) }\end{array}$ & $0.545 \pm 0.040$ & Not detected & $0.067 \pm 0.009$ & Not detected \\
\hline $\begin{array}{c}\text { Cell suspension culture } \\
\left(\mathrm{MS}+2,4-\mathrm{D} 1.0 \mathrm{mg} \cdot \mathrm{l}^{-1}+\mathrm{KIN} 0.1 \mathrm{mg} \cdot \mathrm{l}^{-1}\right) \\
\text { from stationary phase (dark) }\end{array}$ & Not detected & Not detected & Not detected & Not detected \\
\hline
\end{tabular}

2,4-D - dichlorophenoxyacetic acid; DIC - dicamba; KIN - kinetin; MS - Murashige and Skoog medium;

*expressed as chlorogenic acid equivalent

present in the tested callus was chlorogenic acid. Dicaffeoylquinic acid and quercetin hexoside were not detected in both cell cultures (Table 2). The production of chlorogenic acid in the cell suspension cultures was already studied for some medicinal plants i.e.: Eryngium planum [24], Eucommia ulmoides [25], Lonicera macranthoids [26], Coffea arabica [27].

\section{CONCLUSIONS}

The biosynthesis of secondary metabolites in cultured plant cells does not necessary yield compounds characteristic for the intact plant. In this context, the cell suspension culture of Chaenomeles japonica is a promising source of pentacyclic triterpenoids.

\author{
Abbreviations: \\ 2,4-D - dichlorophenoxyacetic acid \\ $\mathrm{BA}$ - betulinic acid \\ DIC - dicamba \\ $\mathrm{GP}$ - growth phase \\ KIN - kinetin \\ MS - Muraschige \& Skoog medium \\ NAA - 1-naphthaleneacetic acid \\ $\mathrm{OA}$ - oleanolic acid \\ SP - stationary phase \\ UA - ursolic acid
}

Conflict of interest: Authors declare no conflict of interest.

\section{REFERENCES}

1. Weber C. The genus Chaenomeles (Rosaceae). J Arnold Arbor 1964; 45:161-205, 302-345 doi: http://dx.doi.org/10.3390/ijms13078943

2. Rumpunen K. Chaenomeles: potential new fruit crop for Northern Europe. In: Janick J, Whipkey A (eds.). Trends in New Crops and New Uses. ASHA Press, Alexandia, VA, USA 2002; 385-392.

3. Hallmann E, Orpel E, Rembiałkowska E. Content of biologically active compounds in some fruits from natural state. Veg Crop Res Bull 2011; 75:81-90 doi: http://dx.doi.org/10.2478/v10032011-0020-8

4. Nahorska A, Dzwoniarska M, Thiem B. Owoce pigwowca japońskiego (Chaenomeles japonica (Thunb.) Lindl. ex Spach) źródłem substancji biologicznie aktywnych. Post Fitoter 2014; 4:239-246.

5. Xu YN, Kim JS, Kang SS, Son K. H, Kim HP, Chang HW et al. A new acylated triterpene from the roots of Chaenomeles japonica. Chem Pharm Bull 2002; 50(8):1124-1125. http://dx.doi. org/10.1248/cpb.50.1124

6. Bae KH. The medicinal plants of Korea. Kyo-Hah Publ Co, Seoul 2000; 213.

7. www.ec.europa.eu

8. Babaloa I, Shode FO. Ubiquitous ursolic acid: a potential pentacyclic triterpene natural product - a review. J Pharmacogn Phytochem 2013; 2(2):214-222. 
9. Yogeeswari P, Sriram D. Betulinic acid and derivations: a review on their biological properties. Curr Med Chem 2005; 12(6):657-666. doi: http:// dx.doi.org/10.2174/0929867053202214

10. Rasouli H, Farzaei MH, Khodarahmi R. Polyphenols and their benefits: A review. Int J Food Prop 2017; 20(2):1700-1741. doi: http://dx.doi.org/10. 1080/10942912.2017.1354017

11. Nabeed M, Hejazi V, Abbas M, Kamboh AA, Khan GJ, Shumazaid M et al. Chlorogenic acid: a pharmacological review and call for further research. Biomed Pharmacother 2018; 97:67-74. doi: http:// dx.doi.org/10.1016/j.biopha.2017.10.064

12. Smetanska I. Production of secondary metabolites using plant cell cultures. Adv Bioch Engin/ Biotechnol 2008; 111:187-228. doi: http://dx.doi. org/10.1007/10_2008_103

13. Yue W, Ming Q-L, Lin B, Rahman K, Zheng Ch-J, Han T et al. Medicinal plant cell suspension cultures: pharmaceutical applications and high-yielding strategies for the desired secondary metabolites. Crit Rev Biotech 2016; 36(2):215-232. doi: http://dx.doi.org/10.3109/07388551.2014.923986

14. Murashige T, Skoog F. A revised medium for rapid growth and bioassays with tobacco cultures. Physiol Plant 1962; 15:473-497.

15. Kikowska M, Włodarczyk A, Rewers M, Sliwinska E, Studzinska-Sroka E, Witkowska-Banaszczak E et al. Micropropagation of Chaenomeles japonica: a step towards production of polyphenol-rich extracts showing antioxidant and antimicrobial activities. Special Issue of Molecules - Phenolic Compounds from Plants: Chemistry, Analysis and Biological Activity 2019; (in press).

16. Kikowska M, Chmielewska M, Włodarczyk A, Studzińska-Sroka E, Żuchowski J, Stochmal A et al. Effect of pentacyclic triterpenes-rich callus extract of Chaenomeles japonica (Thunb.) Lindl. ex Spach on viability, morphology, and proliferation of normal skin fibroblasts. Molecules 2018; 23(11):2003. http://dx.doi.org/10.3390/molecules

17. Yang G, Fen W, Xiao W, Sun H. Study on determination of pentacyclic triterpenoids in Chaenomeles by HPLC-ELSD. J Chromatogr Sci 2009; 47(8): 718-722.

18. Bandhakavi S, Kamarapu P. Production of oleanolic acid by plant tissue culture. J Pharmacogn
Phytochem 2016; 4:1-4.

19. Malinowska M, Sikora E, Ogonowski J. Production of triterpenoids with cell and tissue cultures. Acta Biochim Pol 2013; 60(4):731-735.

20. Srivastava P, Chaturvedi R. Simultaneous determination and quantification of three pentacyclic triterpenoids - betulinic acid, oleanolic acid, and ursolic acid - in cell cultures of Lantana camara L. In Vitro Cell Dev Biol - Plant 2010; 46:549-557. doi: http://dx.doi.org/10.1007/s11627-9298-3

21. Srivastava P, Kasoju N, Bora U, Chaturvedi R. Accumulation of betulinic, oleanolic, and ursolic acids in in vitro cell cultures of Lantana camara L. and their significant cytotoxic effects on HeLa cell lines. Biotech Bioproc Engin 2010; 15:10381046. doi: http://dx.doi.org/10.1007/s12257-0100054-7

22. Skrzypek Z, Wysokińska H. Sterols and triterpenes in cell culture of Hyssopus officinalis L. Z Naturforsch 2010; 58c:308-312. doi: http://dx.doi. org/10.1515/znc-2003-5-602

23. Bonfill M, Mangas S, Moyano E, Cusido RM, Palazon J. Production of centellosides and phytosterols in cell suspension cultures of Centella asiatica. Plant Cell Tiss Organ Cult 2011; 104:61-67. doi: http://dx.doi.org/10.1007/s11240-010-9804-7

24. Kikowska M, Budzianowski J, Krawczyk A, Thiem B. Accumulation of rosmarinic, chlorogenic and caffeic acids in in vitro cultures of Eryngium planum L. Acta Physiol Plant 2012; 34:2425. doi: http://dx.doi.org/10.1007/s11738-012-1011-1

25. Wang J, Liao XL, Zhang H, Du J, Chen P. Accumulation of chlorogenic acid in cell suspension cultures of Eucommia ulmoides. Plant Cell Tiss Organ Cult 2003; 74(2):193-195. doi: http:// dx.doi.org/10.1023/A:1023957129

26. Li Q, Tang M, Tan Y, Ma D, Wang Y, Zhang H. Improved production of chlorogenic acid from cell suspension cultures of Lonicera macranthoids. Trop J Pharm Res 2016; 15(5):919-927. doi: http://dx.doi.org/10.4314/tjpr.v15i5.4

27. Baumann TW, Rohning L. Formation and intracellular accumulation of caffeine and chlorogenic acid in suspension cultures of Coffea arabica. Phytochemistry 1989; 28(10):2667-2669. doi: http:// dx.doi.org/10.1016/S0031-9422(00)98064-6 